\title{
FINANCIAL DISTRESS AND HAPPINESS OF EMPLOYEES IN TIMES OF ECONOMIC CRISIS
}

\author{
E. Arampatzi ${ }^{a}$, M. J. Burger ${ }^{b, *}$ and R. Veenhoven ${ }^{a}$
}

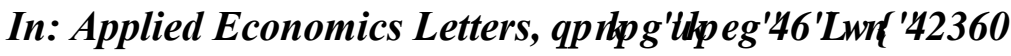

http://dx.doi.org/10.1080/13504851.2014.931916

$\$ \% 675 \$ \& 7$

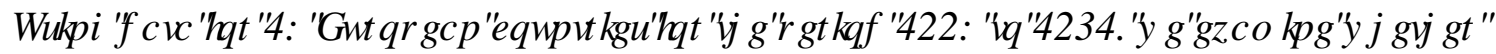

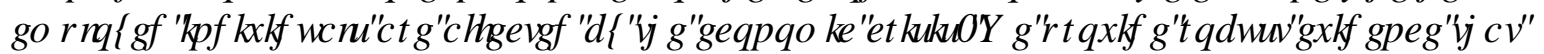

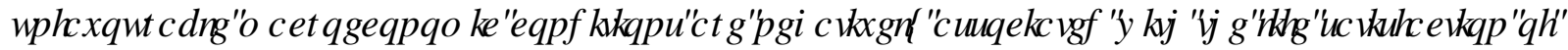

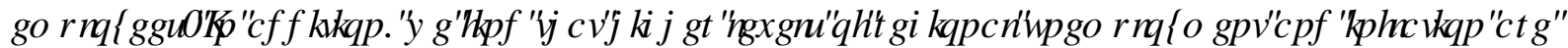

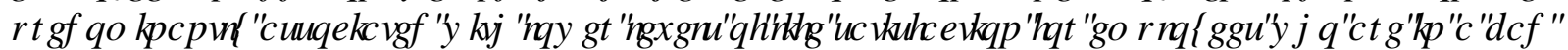

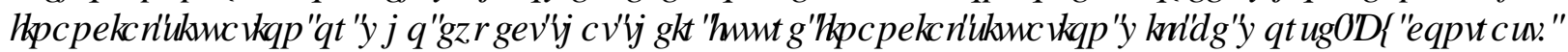

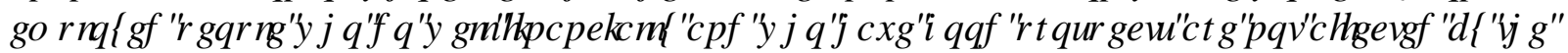
FUMVW

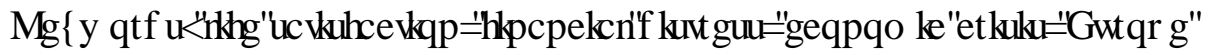

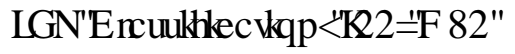

\section{INTRODUCTION:}

\section{Effects of economic recession on life satisfaction}

Economic crises are often characterized as periods of rising unemployment and inflation as well as decreasing material well-being. Not surprisingly, the most recent economic crisis in Europe has accompanied considerable losses in life satisfaction, particularly in several Mediterranean countries (Veenhoven, 2013) in which regional unemployment rates rose as high as $35 \%$.

${ }^{a}$ Erasmus Happiness Economics Research Organization (EHERO), Erasmus University Rotterdam, Rotterdam, The Netherlands

${ }^{b}$ Department of Applied Economics, Erasmus School of Economics, Erasmus Happiness Economics Research Organization (EHERO), Tinbergen Institute, Erasmus University Rotterdam, Rotterdam, The Netherlands

*Corresponding author. E-mail: mburger@ese.eur.nl 
The negative relationship between unemployment and subjective well-being is well documented in the economic literature and is explained by income loss and by the psychic costs of joblessness related to identity problems, psychological distress and low selfesteem (Veenhoven and Hagenaars, 1989; Gallie and Russell, 1998). However, economic crises also tend to affect the subjective well-being of those who manage to keep their jobs (Di Tella et al., 2003). As noted by Frey (2007), this phenomenon can be explained not only by the effect of economic crises on crime, public expenditures and income inequality but also by their effect on the financial distress of households. This financial distress can originate from the need to support unemployed family members, increased inflation, reduced average well-being and career prospects (Blanchflower and Oswald, 1994), longer working hours without overtime compensation (Stewart and Swaffield, 1997) and increased fear of becoming unemployed in the near future and losing material well-being (Luechinger et al., 2010). There is a growing body of literature on the relationship between job insecurity and subjective well-being in times of crisis (e.g., Clark et al., 2010; Luechinger et al., 2010; Green, 2011), but there is relatively little empirical evidence on how financial distress moderates the relationship between macroeconomic conditions and the life satisfaction of employees (for an exception, see Gudmundsdottir, 2013). It can be expected that the more an employee is attached to and reliant on his job to make ends meet, the higher the fear of losing this job and the more that worsening macroeconomic conditions negatively affect the employee's life satisfaction. Employees who are highly dependent on their jobs typically include blue-collar workers (Naswall and De Witte, 2003) and employees with lower education or in low-skilled occupations (Fugate et al., 2004). These groups have the lowest-paying jobs and a lower degree of employability or substantially lower chances to find alternative employment (Sverke et al., 2004).

\section{ECONOMETRIC FRAMEWORK}

To examine the relationships among financial distress, macroeconomic conditions and life satisfaction, we specify a simple reduced-form life satisfaction model (see also Di Tella et al., 2003; Frey et al., 2009): vector of time dummies included to capture global time-related external shocks and $\mathrm{j}$ is a residual error.

\section{DATA}

Annual data on life satisfaction and personal characteristic variables for employees in the EU-28 (excluding Malta) and Iceland are taken from the Eurobarometer Survey Series. Overall, our sample consists of approximately 50000 observations between 2008 and 2012.

Subjective well-being is measured using a 4-point scale measure of life satisfaction on the following question: 'On the whole, are you very satisfied, fairly satisfied, not very satisfied, or not at all satisfied with the life you lead?'. Possible answers are (1) not at all satisfied, (2) not satisfied, (3) fairly satisfied and (4) very satisfied.

To capture an employee's financial distress, we include variables related to the financial situation of the household and the future financial expectations of the household. The financial situation of the household corresponds to the following question: 'How would you judge the current financial situation of your household?'. Respondents choose between 'very bad', 'rather 
bad', 'rather good' and 'very good'. Likewise, our measure of financial expectations is measured by a self-report measure asking "What are your expectations for the next twelve months: will the next twelve months be "better", "worse", or the "same", when it comes to the financial situation of your household?'.

Other personal characteristics included in the analysis are related to gender, age, marital status, household composition, education and occupation type. ${ }^{3}$ With respect to macroeconomic conditions, we include variables related to the unemployment rate, GDP per capita and inflation. Data on the unemployment rate are measured at the regional level (NUTS- 2) and obtained from Eurostat. Information on GDP per capita and inflation rates (consumer prices) are measured at the national level and obtained from the World Bank Development Indictors. ${ }^{4}$ An overview where LSju is a self-report measure of life satisfaction for individual $\mathrm{j}$ in region $\mathrm{i}$ in year $\mathrm{t}$, Financial Distressj $j_{i t}$ is a vector of self-report measures of financial distress, Macro $_{i t}$ is a vector of macroeconomic characteristics in region $i$ in year $t$, Personal $j_{i t}$ is a vector of other personal characteristics of the employees, $\mathrm{e}_{i}$ is a vector of region (NUTS-2) ${ }^{1}$ dummies $^{2}$ to control for time-invariant regional characteristics, $\mathrm{X}_{t}$ is a of all variables included in the analysis and descriptive statistics are provided in Appendices 1 and 2, respectively.

\section{$L S_{j i t}=\boldsymbol{\Theta}$ Macro $_{i t}+\mathbf{\Omega}$ Financial Distress $_{j i t}$ $\mid \sum$ Personal $_{j i t} \mid \varepsilon_{i}+\lambda_{t}+\mu_{j i t}$}

\section{EMPIRICAL RESULTS}

Given the categorical nature of our dependent variable $\mathrm{LS}_{\mathrm{jit}}$, all models were estimated using ordered probit regressions. ${ }^{5}$ Table 1 presents the results using the full sample of employees. Financial distress is negatively associated with life satisfaction (column (1)). Compared to employees who are in a good to very good financial situation, employees who are in a bad or very bad financial situation are less satisfied. Likewise, employees who expect that the future financial situation of their household will worsen are generally less happy than employees who expect that the future financial situation of their household will improve or remain the same (column (2)). Turning to the effects of macroeconomic conditions on life satisfaction (Table 1, columns (3) and (4)), we find that the regional unemployment rate and inflation are negatively associated with the life satisfaction of employees. By contrast, we find no significant correlation between GDP per capita and individual life satisfaction.

Tables 2 and 3 examine the hypothesis that the relationship between macroeconomic conditions and life satisfaction is contingent on the financial distress levels of employees. Here, we partition the sample by (1) the financial situation of the household and (2) the financial expectations of the household. Table 2 presents the results by the financial situation of the household. Although we find evidence of a strong negative association between the regional unemployment rate and life satisfaction for employees in a very bad financial situation, the regional unemployment rate is not correlated with the life satisfaction of employees in a very good financial situation. The regional unemployment rate is also negatively associated with the life satisfaction of employees who are in a rather good or rather bad financial situation, but these 
groups seem to be less deterred by increasing unemployment rates. Similar results are found with regard to inflation, whereas the effect of GDP per capita does not seem to vary by the financial situation of the household. Table 3 shows the results for the different groups delimited by expectations regarding the financial situation of the household. The results support the notion that the responsiveness of life satisfaction to macroeconomic conditions differs between the three groupings. Whereas regional unemployment and inflation are negatively correlated with the life satisfaction of employees who expect that the financial situation of their household will worsen in the near future, regional unemployment and inflation are not associated with the life satisfaction of employees who expect that the financial situation of their household will improve. ${ }^{6}$

The reported differences between the different groups are not only statistically significant but also meaningful from a substantive point of view. Table 4 shows the percentage point change for those who become unhappy (not at all satisfied or not satisfied) by changes in the regional unemployment rate. In line with expectations, it appears that a 5-percentage- point increase in the regional unemployment rate would increase the percentage of unhappy employees who are in a bad financial situation by 6.4 percentage points. An equal increase in the regional unemployment rate would increase the group of unhappy employees in a rather good financial situation by only 1.1 percentage points. Similar conclusions can be drawn when comparing employees by expectations.

\section{DISCUSSION AND CONCLUSION}

Employees who are in financial distress are negatively affected by rising unemployment and inflation, but financially safe employees are not. Because employees in financial distress can be disproportionately found in groups that are already generally less satisfied with life (i.e., lowereducated, low-skilled, blue-collar workers), economic crises can increase inequality in subjective well-being. This finding should be further examined in future research.

Such an effect should be interpreted with caution. The indicators regarding the measurement of financial distress (financial situation of the household and future expectations) are subjective. It is possible that individuals change their reference point when their evaluation of financial matters is performed during recession periods. Decreased life satisfaction during recessions cannot be justified only by financial difficulties. Future research could address whether other social and economic conditions, such as increased crime, reduced public expenditures or income inequality (Frey, 2007), moderate the relationship between crisis and life satisfaction. 


\section{REFERENCES}

Blanchflower, D. G. and Oswald, A. J. (1994)

The Wage Curve, MIT Press, Boston, MA.

Clark, A., Knabe, A. and Ratzel, S. (2010)

Boon or bane? Others' unemployment, well-being and job insecurity,

Labour Economics, 17, 52-61. doi: 10.1016/j. labeco.2009.05.007.

Di Tella, R., Macculloch, R. J. and Oswald, A. J. (2003)

The macroeconomics of happiness,

The Review of Economics and Statistics, 85, 809-27. doi:10.1162/ 003465303772815745.

Frey, B. S. (2007) Happiness: A Revolution in Economics, MIT Press, Boston, MA.

Frey, B. S., Luechinger, S. and And Stutzer, A. (2009)

The life satisfaction approach to valuing public goods: the case of terrorism,

Public Choice, 138, 317-45. doi:10.1007/s11127-008-9361-3.

Fugate, M., Kinicki, A. J. and Ashforth, B. E. (2004)

Employability: a psycho-social construct, its dimensions, and applications, Journal of Vocational Behavior, 65, 14-38. doi:10.1016/j.jvb.2003.10.005.

Gallie, D. and Russell, H. (1998)

Unemployment and life satisfaction: a cross-cultural comparison, European Journal of Sociology, 39, 248-80. doi:10.1017/ S0003975600007633.

Green, F. (2011)

Unpacking the misery multiplier: how employability modifies the impacts of unemployment and job insecurity on life satisfaction and mental health, Journal of Health Economics, 30, 265-76. doi:10.1016/j.jhealeco.2010.12.005.

Gudmundsdottir, D. G. (2013)

The impact of economic crisis on happiness,

Social Indicators Research, 110, 1083-101. doi:10.1007/s11205-011-9973-8.

Luechinger, S., Meier, S. and Stutzer, A. (2010)

Why does unemployment hurt the employed? Evidence from the life satisfaction gap between the public and the private sector,

Journal of Human Resources, 45, 998-1045. doi:10.1353/jhr.2010.0024.

Naswall, K. and De Witte, H. (2003)

Who feels insecure in Europe? Predicting job insecurity from background variables, Economic and Industrial Democracy, 24, 189-215. doi:10.1177/ 0143831X03024002003. 
Stewart, M. B. and Swaffield, J. K. (1997)

Constraints on the desired hours of work of British men, The Economic Journal, 107, 520-35. doi: 10.1111/ j.0013-0133.1997.175.x.

Sverke, M., Helgrenn, J., Naswall, K. et al. (2004)

Job Insecurity and Union Membership: European Unions in the Wake of Flexible Production, Peter Lang, Brussels.

Veenhoven, R. (2013) Happiness in Nations.

World Database of Happiness, Erasmus University Rotterdam, The Netherlands.

Veenhoven, R. and Hagenaars, A. (Eds.) (1989)

Did the Crisis Really Hurt? Effects of the 1980-82 Economic Recession

on Satisfaction, Mental Health and Mortality,

Universitaire Pers Rotterdam, Rotterdam. 


\section{NOTES}

${ }^{1}$ The Nomenclature of Territorial Units for Statistics (NUTS) classification is a geocode standard to subdivide the economic territory of the European Union. NUTS-2 regions are basic regions for application of regional policies and normally have a population of 800000 to 3 million.

${ }^{2}$ The dummy controls for 205 European regions for which coefficients were found to be significant.

${ }^{3}$ Type of occupation distinguishes between blue-collar versus white-collar labour and low-skilled versus high-skilled occupations according to 'Eurostat's Adult Education Survey.

${ }^{4}$ Unfortunately, there were no recent GDP per capita and inflation data available at the regional level.

${ }^{5}$ A challenge here is that unhappiness and financial distress often go hand in hand and may, in fact, aggravate each other. Moreover, there is a possibility of reverse causality, with increasing unhappiness exacerbating financial distress. One solution to this problem would be to instrument financial distress, but finding credible instruments is difficult. Instead, we recognize this problem and caution that our results should be interpreted as conditional associations rather than reflecting causal relationships.

${ }^{6}$ The negative and significant correlation for GDP per capita in the regression for employees who expect that the financial situation of their household will worsen may be explained by social comparison effects and requires further examination. 


\section{Table 1.}

\section{Life satisfaction of the employed, ordered probit regressions}

\begin{tabular}{|c|c|c|c|c|}
\hline & (1) & (2) & (3) & (4) \\
\hline \multicolumn{5}{|l|}{ Macroecononic characteristics } \\
\hline Regional unemployment rate & & & $\begin{array}{c}-0.022 * * \\
(0.004)\end{array}$ & $\begin{array}{c}-0.017 * * \\
(0.005)\end{array}$ \\
\hline GDP per capita & & & $\begin{array}{c}0.017 \\
(0.009)\end{array}$ & $\begin{array}{c}-0.003 \\
(0.011)\end{array}$ \\
\hline Inflation & & & $\begin{array}{l}-0.011^{* *} \\
(0.004)\end{array}$ & $\begin{array}{c}-0.012^{* *} \\
(0.004)\end{array}$ \\
\hline \multicolumn{5}{|l|}{ Personal characteristics } \\
\hline Female & $\begin{array}{c}0.003 \\
(0.011)\end{array}$ & $\begin{array}{c}-0.051^{* *} \\
(0.011)\end{array}$ & $\begin{array}{c}0.004 \\
(0.011)\end{array}$ & $\begin{array}{c}-0.050^{* *} \\
(0.011)\end{array}$ \\
\hline Married & $\begin{array}{l}0.219^{* * *} \\
(0.014)\end{array}$ & $\begin{array}{l}0.164^{* *} \\
(0.013)\end{array}$ & $\begin{array}{l}0.221^{* *} \\
(0.012)\end{array}$ & $\begin{array}{l}0.167^{* *} \\
(0.014)\end{array}$ \\
\hline \multicolumn{5}{|l|}{ Age } \\
\hline Between 15 and 24 years & $\begin{array}{c}0.366^{* *} \\
(0.024)\end{array}$ & $\begin{array}{c}0.283^{* *} \\
(0.025)\end{array}$ & $\begin{array}{c}0.368 * * \\
(0.023)\end{array}$ & $\begin{array}{c}0.285^{* *} \\
(0.025)\end{array}$ \\
\hline Older than 55 years & $\begin{array}{c}-0.054^{* *} \\
(0.016)\end{array}$ & $\begin{array}{l}-0.054^{* *} \\
(0.016)\end{array}$ & $\begin{array}{c}-0.059 * * \\
(0.016)\end{array}$ & $\begin{array}{c}-0.060^{* *} \\
(0.017)\end{array}$ \\
\hline \multicolumn{5}{|l|}{ Children } \\
\hline One child & $\begin{array}{c}0.004 \\
(0.014)\end{array}$ & $\begin{array}{l}0.042^{* *} \\
(0.015)\end{array}$ & $\begin{array}{c}0.002 \\
(0.014)\end{array}$ & $\begin{array}{l}0.040^{* *} \\
(0.015)\end{array}$ \\
\hline Two or more children & $\begin{array}{c}0.022 \\
(0.016)\end{array}$ & $\begin{array}{c}0.074^{* *} \\
(0.0 \mid 6)\end{array}$ & $\begin{array}{c}0.020 \\
(0.015)\end{array}$ & $\begin{array}{l}0.071^{* *} \\
(0.016)\end{array}$ \\
\hline \multicolumn{5}{|l|}{ Education to age } \\
\hline$<15$ years old & $\begin{array}{l}-0.299 * * \\
(0.025)\end{array}$ & $\begin{array}{l}-0.163^{* *} \\
(0.025)\end{array}$ & $\begin{array}{l}-0.297^{* *} \\
(0.023)\end{array}$ & $\begin{array}{c}-0.160^{* *} \\
(0.025)\end{array}$ \\
\hline $15-18$ ycars old & $\begin{array}{c}-0,188^{* *} \\
(0,013)\end{array}$ & $\begin{array}{l}-0.118^{* *} \\
(0.013)\end{array}$ & $\begin{array}{c}-0.186 * * \\
(0.013)\end{array}$ & $\begin{array}{c}-0.115^{* *} \\
(0.013)\end{array}$ \\
\hline Bluc-collar labour & $\begin{array}{l}-0.344^{* *} \\
(0.015)\end{array}$ & $\begin{array}{l}-0.177^{* *} \\
(0.015)\end{array}$ & $\begin{array}{c}-0.344^{* *} \\
(0.014)\end{array}$ & $\begin{array}{c}-0.179^{* *} \\
(0.015)\end{array}$ \\
\hline Low-skilled labour & $\begin{array}{c}-0.185^{* *} \\
(0.013)\end{array}$ & $\begin{array}{l}-0.086^{* *} \\
(0.013)\end{array}$ & $\begin{array}{l}-0.179 * * \\
(0.012)\end{array}$ & $\begin{array}{l}-0.082^{* *} \\
(0.013)\end{array}$ \\
\hline \multicolumn{5}{|l|}{ Financiat sintation } \\
\hline Rather good & & $\begin{array}{c}-0.790^{* *} \\
(0.028)\end{array}$ & & $\begin{array}{c}-0.782^{* *} \\
(0.028)\end{array}$ \\
\hline Rather bad & & $\begin{array}{c}-1.607^{* *} \\
(0.034)\end{array}$ & & $\begin{array}{l}-1.600^{*} \\
(0.034)\end{array}$ \\
\hline Very bad & & $\begin{array}{l}-2.254^{* *} \\
(0.049)\end{array}$ & & $\begin{array}{l}-2.244^{* *} \\
(0.050)\end{array}$ \\
\hline \multicolumn{5}{|c|}{ Financial expectations next year } \\
\hline Same & & $\begin{array}{l}-0.162 * * \\
(0.015)\end{array}$ & & $\begin{array}{c}-0.160^{* *} \\
(0.015)\end{array}$ \\
\hline Worse & & $\begin{array}{c}-0.410^{* *} \\
(0.019)\end{array}$ & & $\begin{array}{c}-0.403^{* *} \\
(0.019)\end{array}$ \\
\hline Region dummics & Yes & Yes & Yes & Yes \\
\hline Year dummies & Yes & Yes & Yes & Yes \\
\hline Pscudo- $R^{2}$ & 0.161 & 0.246 & 0.164 & 0.248 \\
\hline Observations & 50268 & 49272 & 47912 & 46962 \\
\hline
\end{tabular}

Notes: Cluster-robust SEs are given in parentheses. ${ }^{* *} \mathrm{p}<0.01$. 
Table 2.

Life satisfaction of the employed by financial situation, ordered probit regressions

\begin{tabular}{|c|c|c|c|c|}
\hline & $\begin{array}{l}\text { Very good financial } \\
\text { situation }\end{array}$ & $\begin{array}{l}\text { Rather good financial } \\
\text { situation }\end{array}$ & $\begin{array}{l}\text { Rather bad financial } \\
\text { situation }\end{array}$ & $\begin{array}{l}\text { Very bad financial } \\
\text { situation }\end{array}$ \\
\hline \multicolumn{5}{|c|}{ Macroesonomic characteristics } \\
\hline $\begin{array}{l}\text { Regional } \\
\text { unemployment } \\
\text { rate }\end{array}$ & $\begin{array}{l}0.018 \\
(0.019)\end{array}$ & $\begin{array}{l}-0.019 * * \\
(0.007)\end{array}$ & $\begin{array}{l}-0.016 * * \\
(0.004)\end{array}$ & $\begin{array}{l}-0.043^{* *} \\
(0.016)\end{array}$ \\
\hline GDP per capita & $\begin{array}{c}0.034 \\
(0.028)\end{array}$ & $\begin{array}{c}0.0099 \\
(0.015)\end{array}$ & $\begin{array}{c}0.002 \\
(0.018)\end{array}$ & $\begin{array}{l}-0.039 \\
(0.041)\end{array}$ \\
\hline Inflation & $\begin{array}{c}0.024 \\
(0.020)\end{array}$ & $\begin{array}{c}0.007 \\
(0.006)\end{array}$ & $\begin{array}{l}-0.024 * * \\
(0.006)\end{array}$ & $\begin{array}{l}-0.044^{* *} \\
(0.015)\end{array}$ \\
\hline $\begin{array}{l}\text { Pensonal } \\
\text { characteristics }\end{array}$ & Yes & Yes & Yes & Yes \\
\hline Region dummies & Yes & Yes & Yes & Yes \\
\hline Year dummies & Yes & Yes & Yes & Yes \\
\hline Pscudo- $R^{2}$ & 0.105 & 0.120 & 0.102 & 0.13 \\
\hline Observations & 5217 & 27822 & 11978 & 2587 \\
\hline
\end{tabular}

Notes: Cluster-robust SEs are given in parentheses. ${ }^{* *} p<0.01$. 
Table 3.

Life satisfaction of the employed by financial expectations, ordered probit regressions

\begin{tabular}{|c|c|c|c|}
\hline & $\begin{array}{l}\text { lixpected } \\
\text { finaneial } \\
\text { situation: } \\
\text { better }\end{array}$ & $\begin{array}{l}\text { lixpected } \\
\text { financial } \\
\text { situation: } \\
\text { same }\end{array}$ & $\begin{array}{l}\text { lixpected } \\
\text { financial } \\
\text { situation: } \\
\text { worse }\end{array}$ \\
\hline \multicolumn{4}{|c|}{ Macroeconomic characteristics } \\
\hline $\begin{array}{l}\text { Regional } \\
\text { unemployment rate }\end{array}$ & $\begin{array}{l}-0.008 \\
(0.008)\end{array}$ & $\begin{array}{l}-0,016^{* *} \\
(0,006)\end{array}$ & $\begin{array}{l}-0.036 * * \\
(0.004)\end{array}$ \\
\hline GDP per capita & $\begin{array}{c}0.019 \\
(0.017)\end{array}$ & $\begin{array}{c}0.020 \\
(0.012)\end{array}$ & $\begin{array}{l}-0.063^{* *} \\
(0.017)\end{array}$ \\
\hline Inflation & $\begin{array}{l}-0.007 \\
(0.010)\end{array}$ & $\begin{array}{l}-0.003 \\
(0.006)\end{array}$ & $\begin{array}{c}-0.017^{*} \\
(0.007)\end{array}$ \\
\hline Personal charactertistics & Yes & Yes & Yes \\
\hline Region dummies & Yes & Yes & Yes \\
\hline Year dummics & Yes & Yes & Yes \\
\hline Pscudo- $R^{2}$ & 0.127 & 0.176 & 0.157 \\
\hline Observations & 9860 & 26762 & 10597 \\
\hline
\end{tabular}

Notes: Cluster-robust SEs are given in parentheses.

$* * \mathrm{p}<0.01$.

$* \mathrm{p}<0.05$. 


\section{Table 4.}

Percentage point change of employed that are unhappy (rather dissatisfied or very dissatisfied) by financial situation and financial expectations

\begin{tabular}{llll}
\hline & $\begin{array}{l}\text { Unemployment } \\
-1 \%\end{array}$ & $\begin{array}{l}\text { Unemployment } \\
-5 \%\end{array}$ & $\begin{array}{l}\text { Unemployment } \\
-10 \%\end{array}$ \\
\hline All employees & $0.4 \%$ & $1.9 \%$ & $3.9 \%$ \\
Financial situation & $-0.0 \%$ & $-0.0 \%$ & $-0.0 \%$ \\
Very good & $0.0 \%$ & $1.1 \%$ & $2.4 \%$ \\
Rather good & $0.6 \%$ & $2.8 \%$ & $5.6 \%$ \\
Rather bad & $1.4 \%$ & $6.4 \%$ & $11.8 \%$ \\
Very bad & & & \\
Financial & $0.0 \%$ & $0.0 \%$ & $0.1 \%$ \\
expectations & $0.3 \%$ & $1.4 \%$ & $2.9 \%$ \\
Better & $1.2 \%$ & $6.0 \%$ & $12.1 \%$ \\
Same & & & \\
Worse & & & \\
\hline
\end{tabular}




\section{Appendix 1 \\ Description of variables}

\begin{tabular}{|c|c|c|c|}
\hline \multicolumn{4}{|l|}{ Dependent variable } \\
\hline Life satisfaction & Categorical & $\begin{array}{l}\text { Very satisfied, fairly satisfied, not } \\
\text { very satisfied, not at all satisfied }\end{array}$ & liurobarometer \\
\hline \multicolumn{4}{|l|}{ Personal characteristics } \\
\hline $\begin{array}{l}\text { Expectations (next } 12 \text { months) for } \\
\text { financial situation }\end{array}$ & Categorical & Better, worse, same & Eurobarometer \\
\hline Financial situation of the household & Categorical & $\begin{array}{l}\text { Very good, rather good, rather bad, } \\
\text { very bad }\end{array}$ & l:urobarometer \\
\hline Age group & Categorical & $15-24,25-54,55+$ & l:urobarometer \\
\hline Gender & Categorical & Femalemale & Jurobarometer \\
\hline Marital status & Categorical & Marricd/otherwisc & liurobarometer \\
\hline Occupation & Categorical & Uncmployed/limployed & liurobarometer \\
\hline Children & Categorical & None, 1 child, 2 or more & liurobarometer \\
\hline liducation to age & Categorical & $<15,15-18,>20$ & liurobarometer \\
\hline Type of job & Categorical & $\begin{array}{l}\text { Blue-collar versus white-collar } \\
\text { High-skilled versus Low-skilled }\end{array}$ & $\begin{array}{l}\text { Own calculation based on } \\
\text { liurostat ISCO-88 Code }\end{array}$ \\
\hline \multicolumn{4}{|l|}{ Macmeconomic characteristics } \\
\hline Regional unemployment rate $(\%)$ & Continuous & & lurostat \\
\hline $\begin{array}{l}\text { GDP per capita PPP (constant } 2005 \\
\text { international \$) }\end{array}$ & Continuous & & World Bank \\
\hline Inflation rate (consumer prices $\%$ ) & Continuous & & World Bank \\
\hline
\end{tabular}




\section{Appendix 2 \\ Descriptive statistics}

\begin{tabular}{|c|c|c|c|c|c|}
\hline & Mean & $\mathrm{SD}$ & Minimum & Maximum & $N$ \\
\hline Life satisfaction & 2.97 & 0.75 & l & 4 & 50268 \\
\hline \multicolumn{6}{|l|}{ Macroeconomic characteristics } \\
\hline Regional unemployment rate & 8.97 & 4.47 & 1.9 & 34.6 & 50426 \\
\hline GDP per capita & 26.93 & 10.18 & 10.72 & 72.18 & 48203 \\
\hline Inflation & 2.97 & 2.55 & -4.47 & 15.40 & 50426 \\
\hline \multicolumn{6}{|l|}{ Personal characteristics } \\
\hline Female & 0.48 & 0.50 & 0 & 1 & 50426 \\
\hline Mariced & 0.63 & 0.48 & 0 & 1 & 50426 \\
\hline \multicolumn{6}{|l|}{ Age } \\
\hline Between 15 and 24 years & 0.07 & 0.25 & 0 & 1 & 50426 \\
\hline Older than 55 years & 0.16 & 0.37 & 0 & l & 50426 \\
\hline \multicolumn{6}{|l|}{ Chitdren } \\
\hline Onc Child & 0.19 & 0.39 & 0 & 1 & 50 426 \\
\hline Two or more children & 0.18 & 0.38 & 0 & 1 & 50426 \\
\hline \multicolumn{6}{|l|}{ Education to age } \\
\hline$<15$ years old & 0.10 & 0.30 & 0 & 1 & 50426 \\
\hline $15-18$ ycars old & 0.54 & 0.50 & 0 & l & 50426 \\
\hline Bluc-collar labour & 0.32 & 0.46 & 0 & 1 & 50 426 \\
\hline Low-skilled labour & 0.51 & 0.50 & 0 & 1 & 50 426 \\
\hline \multicolumn{6}{|l|}{ Financial sinuation } \\
\hline Rather good & 0.59 & 0.49 & 0 & 1 & 50068 \\
\hline Rather bad & 0.25 & 0.44 & 0 & 1 & 50068 \\
\hline Very bad & 0,05 & 0.23 & 0 & 1 & 50068 \\
\hline \multicolumn{6}{|l|}{ Financial expectations next year } \\
\hline Same & 0.57 & 0.49 & 0 & 1 & 49681 \\
\hline Worse & 0.23 & 0.42 & 0 & 1 & 49681 \\
\hline
\end{tabular}

